\title{
Peranan dan Kedudukan Paralegal Dalam Pemberian Bantuan Hukum Bagi Masyarakat Miskin di Kabupaten Bojonegoro
}

\author{
Andrianto Prabowo ${ }^{1)}$, M. Abdim Munib ${ }^{2)}$ \\ ${ }^{1}$ Fakultas Hukum Universitas Bojonegoro \\ Email : andri.bjn@gmail.com \\ ${ }^{2}$ Fakultas Hukum Universitas Bojonegoro \\ Email : munifkpusbjn@gmail.com
}

\begin{abstract}
ABSTRAK
Penelitian ini bertujuan untuk mengetahui peranan dan kedudukan Paralegal dalam pemberian bantuan hukum bagi masyarakat miskin di Kabupaten Bojonegoro. Jenis penelitian ini merupakan penelitian normatif empiris, menggunakan pendekatan peraturan perundang-undangan, konseptual, dan pendekatan kasus. Pengumpulan bahan hukum yaitu dengan menggunakan pendekatan kepustakaan, kemudian dianalisis secara sistematis. Hasil penelitian menunjukan bahwa peranan dan kedudukan Paralegal dalam pemberian bantuan hukum bagi masyarakat miskin di Kabupaten Bojonegoro adalah sebagai penunjang tugas dan fungsi Advokat pada Lembaga Bantuan Hukum (LBH) atau pada Pemberi Bantuan Hukum lainnya.
\end{abstract}

Kata Kunci : Peranan, Kedudukan, Paralegal, Masyarakat, Miskin

\section{PENDAHULUAN}

Konsep negara hukum menempatkan hukum pada tingkatan paling tinggi (supremacy of law). Di dalam pelaksanaannya harus menghormati hak asasi manusia, pemisahan kekuasaan, adanya peradilan yang independen dan segala tindakan negara yang termanifestasi oleh alat kelengkapan negara harus didasari oleh undangundang. Adrian W. Bedner menyatakan fungsi negara hukum adalah membatasi kesewenang-wenangan dari penggunaan yang tidak semestinya dari kekuasaan negara dan melindungi kepemilikan dan keselamatan warga dari pelanggaran dan serangan warga lainnya. ${ }^{1}$

Setiap warga negara mempunyai kedudukan yang sama di atas hukum dan

\footnotetext{
1 YLBHI, Panduan Bantuan Hukum Indonesia, Yayasan Obor Indonesia, Jakarta, 2014, hal. 466.
}

pemerintahan $^{2}$, atau dalam dunia hukum sering disebut dengan istilah equality berfore the law. Hal ini sudah menjadi jaminan konstitusi kita bahwa setiap warga negara harus diperlakukan sama di hadapan hukum dan pemerintahan, tanpa membedakan suku, ras, maupun golongan. Dengan begitu, maka untuk memenuhi amanat konstitusi tersebut, Negara lah yang harus hadir untuk menyelesaikan persoalan-persoalan hukum yang dihadapi oleh setiap warga negara, terlebih bagi mereka yang memang kurang mampu secara ekonomi. Oleh karena itu, setiap orang yang tersangkut perkara berhak untuk mendapatkan bantuan hukum baik dalam perkara perdata, pidana, maupun sengketa tata usaha negara. Bantuan hukum tersebut diberikan baik dalam bentuk litigasi maupun non litigasi, dan

\footnotetext{
${ }^{2}$ Lihat dalam ketentuan Pasal 27 ayat (1) UndangUndang Dasar Negara Republik Indonesia Tahun 1945.
} 
Pemerintah sebagai penyelenggara negara memiliki tanggung jawab dalam pemenuhan hak atas bantuan hukum sebagai salah satu hak konstitusional warga Negara.

Seiring berjalannya waktu Peraturan Menteri Hukum dan Hak Asasi Manusia Nomor 1 Tahun 2018 tentang Paralegal dalam Pemberian Bantuan Hukum tersebut tidak bertahan lama setelah adanya Putusan Mahkamah Agung No.22/P/HUM/2018 yang menyatakan bahwa Pasal 11 dan Pasal 12 Peraturan tersebut bertentangan dengan UndangUndang Nomor 18 Tahun 2003 tentang Advokat, dan karenanya tidak berlaku umum. Sehingga bantuan hukum oleh paralegal masih kurang efektif di Indonesia karena peran paralegal dalam pemberian layanan bantuan hukum, sangat urgen eksistensinya, mengingat banyaknya masyarakat miskin, marjinal dan buta hukum di Indonesia yang sulit mendapatkan akses terhadap keadilan, apalagi jumlah penduduk yang padat dan menyebar di berbagai wilayah yang luas khususnya di Kabupaten Bojonegoro, sehingga tidak sebanding dengan jumlah Advokat yang tersedia.

Berdasarkan uraian pada latar belakang tersebut di atas mendorong peneliti untuk mengangkat tema penelitian ini tentang "Peranan dan Kedudukan Paralegal Dalam Pemberian Bantuan Hukum Bagi Mayarakat Miskin di Kabupaten Bojonegoro". Berdasarkan uraian tersebut di atas, maka permasalahan yang diajukan dalam penelitian ini adalah terkait peranan dan kedudukan Paralegal dalam pemberian bantuan hukum bagi masyarakat miskin di Kabupaten Bojonegoro.

\section{METODE PENELITIAN}

Dalam penelitian ini menggunakan Jenis penelitian hukum normatif empiris. Di dalam penelitian ini, metode pendekatan yang digunakan adalah Pendekatan Perundang-Undangan
(Statute Approach) dan Pendekatan Konsep (Conseptual Approach). ${ }^{3}$

Bahan hukum primer ini dari membaca peraturan dasar, peraturan perundang-undangan, dan norma hukum, meliputi :

1. Undang-Undang Dasar Negara Republik Indonesia 1945;

2. Undang-Undang Nomor 8 Tahun 1981 tentang Hukum Acara Pidana;

3. Undang-Undang Nomor 18 Tahun 2003 tentang Advokat.

4. Undang-Undang Nomor 48 Tahun 2009 tentang Kekuasaan Kehakiman

5. Undang-Undang Nomor 16 Tahun 2011 tentang Bantuan Hukum

6. Peraturan Menteri Hukum dan Hak Asasi Manusia Nomor 1 Tahun 2018 tentang Paralegal Dalam Pemberian Bantuan Hukum.

\section{HASIL DAN PEMBAHASAN}

Peranan Paralegal dalam pemberian bantuan hukum, terutama bagi masyarakat yang kurang mampu di Kabupaten Bojonegoro memang sangat penting dan dibutuhkan sekali. Karena Paralegal itu direkrut oleh Pemberi Bantuan Hukum, yang mana Pemberi bantuan hukum yang dimaksud adalah memberikan jasa hukumnya secara cumacuma atau gratis dan dikhususkan untuk orang atau kelompok orang yang miskin secara ekonomi. Upaya ini adalah sebagai perwujudan amanat konstitusi kita yakni Undang-Undang Dasar Negara Republik Indonesia Tahun 1945, khususnya Pasal 27 ayat (1) yang menentukan bahwa "Segala warga negara bersamaan kedudukannya di dalam hukum dan pemerintahan dan wajib menjunjung hukum dan pemerintahan itu dengan tidak ada kecualinya".

Sebagaimana diketahui bahwa peranan dan kedudukan Paralegal diakui setelah dikeluarkannya Peraturan Menteri

\footnotetext{
${ }^{3}$ Peter Mahmud Marzuki, Penelitian Hukum, Cet. 5, Edisi Pertama, PT Interpratama Offset, Jakarta, 2009, hal. 93.
} 
Hukum dan Hak Asasi Manusia Nomor 1 Tahun 2018 Tentang Paralegal Dalam Pemberian Bantuan Hukum. Meskipun tidak secara eksplisit mengatur kedudukan dan kewenangan Paralegal, di dalam Undang-Undang Republik Indonesia Nomor 11 Tahun 2016 Tentang Bantuan Hukum, juga telah menyebutkan adanya istilah Paralegal dalam konteks tata hukum Indonesia. ${ }^{4}$ Oleh karena itu, inilah bentuk legitimasi yuridis terhadap eksistensi Paralegal dalam pemberian layanan bantuan hukum bagi masyarakat miskin yang berhadapan dengan masalah hukum, termasuk di Kabupaten Bojonegoro.

Paralegal sebelumnya diberikan kewenangan untuk memberikan bantuan hukum baik secara litigasi maupun nonlitigasi. Hal ini dapat dilihat dalam ketentuan Pasal 11 Permenkumham No. 1 Tahun 2018 yang menentukan bahwa "Paralegal dapat memberikan Bantuan Hukum secara litigasi dan nonlitigasi setelah terdaftar pada Pemberi Bantuan Hukum dan mendapatkan sertifikat pelatihan Paralegal tingkat dasar". Namun ternyata kewenangan Paralegal tersebut mendapatkan penolakan yang masif dari kalangan Advokat. Mengingat untuk dapat diangkat menjadi Advokat dan bisa memberikan jasa hukum baik secara litigasi maupun nonlitigasi, harus lah memenuhi persyaratan-persyaratan ketat yang diatur dalam Undang-Undang Republik Indonesia Nomor 18 Tahun 2003 Tentang Advokat.

\footnotetext{
4 Dalam Pasal 9 huruf (a) Undang-Undang Republik Indonesia Nomor 16 Tahun 2011 Tentang Bantuan Hukum, menentukan bahwa "Pemberi Bantuan Hukum berhak melakukan rekrutmen terhadap Advokat, Paralegal, Dosen, dan mahasiswa Fakultas Hukum". Kemudian dalam Pasal 10 huruf (c) undang-undang tersebut juga menentukan bahwa "menyelenggarakan pendidikan dan pelatihan Bantuan Hukum bagi advokat, paralegal, dosen, mahasiswa fakultas hukum yang direkrut sebagaimana dimaksud dalam Pasal 9 huruf a".
}

Di dalam Pasal 3 Undang-Undang Advokat tersebut ditentukan bahwa "Untuk dapat diangkat menjadi Advokat harus memenuhi persyaratan sebagai berikut :

a. Warga negara Republik Indonesia;

b. Bertempat tinggal di Indonesia;

c. Tidak berstatus sebagai pegawai negeri atau pejabat negara;

d. Berusia sekurang-kurangnya 25 (dua puluh lima) tahun;

e. Berijazah sarjana yang berlatar belakang pendidikan tinggi hukum sebagaimana dimaksud dalam Pasal 2 ayat (1);

f. Lulus ujian yang diadakan oleh Organisasi Advokat;

g. Magang sekurang-kurangnya 2 (dua) tahun terus menerus pada kantor Advokat;

h. Tidak pernah dipidana karena melakukan tindak pidana kejahatan yang diancam dengan pidana penjara 5 (lima) tahun atau lebih;

i. Berperilaku baik, jujur, bertanggung jawab, adil, dan mempunyai integritas yang tinggi.

Bahkan untuk dapat beracara di pengadilan maupun di luar pengadilan, seorang Advokat harus disumpah terlebih dahulu melalui sidang terbuka oleh Pengadilan Tinggi di wilayah domisili hukumnya. ${ }^{5}$ Mari kita bandingkan dengan persyaratan untuk menjadi seorang Paralegal, yang mana oleh Permenkumhan No. 1 Tahun 2018 diberikan kewenangan yang sama seperti layaknya seorang Advokat dalam memberikan jasa hukum.

Di dalam Pasal 4 Permenkumhan No. 1 Tahun 2018 ditentukan bahwa "Untuk dapat direkrut menjadi Paralegal

\footnotetext{
${ }^{5}$ Lihat dalam ketentuan Pasal 4 ayat (1) UndangUndang Republik Indonesia Nomor 18 Tahun 2003 Tentang Advokat. Dimana ditentukan bahwa "Sebelum menjalankan profesinya, Advokat wajib bersumpah menurut agamanya atau berjanji dengan sungguh-sungguh di sidang terbuka Pengadilan Tinggi di wilayah domisili hukumnya".
} 
sebagaimana dimaksud dalam Pasal 3 ayat (2) harus memenuhi persyaratan sebagai berikut:

a. Warga negara Indonesia;

b. Berusia paling rendah 18 (delapan belas) tahun;

c. Memiliki pengetahuan tentang advokasi masyarakat; dan/atau

d. Memenuhi syarat lain yang ditentukan oleh Pemberi Bantuan Hukum.

Berdasarkan uraian tersebut di atas, terlihat jelas bahwa begitu mudahnya untuk menjadi seorang Paralegal dan dapat memberikan bantuan hukum baik secara litigasi maupun nonlitigasi. Kondisi ini tentu melukai rasa keadilan bagi seluruh Advokat di Indonesia. Oleh karena itulah sejumlah Advokat memutuskan untuk mengajukan keberatan uji materil Permenkumham No. 1 Tahun 2018 tersebut ke Mahkamah Agung Republik Indonesia.

Atas Permohonan uji materil tersebut, Mahkamah Agung Republik Indonesi telah memutuskan bahwa Pasal 11 dan Pasal 12 Permenkumham No. 1 Tahun 2018 bertentangan dengan peraturan perundang-undangan yang lebih tinggi, yaitu Undang-Undang Nomor 18 Tahun 2003 Tentang Advokat dan karenanya tidak berlaku umum. Selain itu, Mahkamah Agung juga memerintahkan kepada Menteri Hukum dan Hak Asasi Manusi Republik Indonesia untuk mencabut Pasal 11 dan Pasal 12 Peraturan Menteri Hukum dan Hak Asasi Manusia Republik Indonesia Nomor 01 Tahun 2018 tentang Paralegal Dalam Pemberian Bantuan Hukum. ${ }^{6}$

\footnotetext{
${ }^{6}$ Lihat dalam Direktori Putusan Mahkamah Agung Republik Indonesia Nomor 22 P/HUM/2018 dalam perkara : BIREVEN ARUAN, S.H., JOHAN IMANUEL, S.H., MARTHA DINATA, S.H., ABDUL JABBAR, S.H.I., IRWAN GUSTAF LALEGIT, S.H., IKA ARINI BATUBARA, S.H., DENNY SUPARI, S.H., LIBERTO JULIHARTAMA, S.H., STEVEN ALBERT, S.H., ABDUL SALAM, S.H., ADE ANGGRAINI, S.H.,
}

Putusan Mahkamah Agung tersebut tentu saja dianggap sudah tepat, karena di negara-negara maju sekalipun kedudukan Paralegal adalah tidak lebih dari sekadar asisten Advokat. Itu artinya bahwa tidak dibenarkan seorang Paralegal memberikan bantuan secara litigasi, meskipun itu tujuannya adalah untuk membantu masyarakat yang miskin.

Namun yang menarik untuk diperhatikan adalah terkait dengan kewenangan Paralegal untuk memberikan bantuan hukum secara nonlitigasi sebaimana diatur dalam Pasal 13 Permenkumham tersebut, dan oleh Mahkamah Agung Pasal tersebut tidak dibatalkan. Dimana dalam pasal tersebut ditentukan bahwa "Pemberian Bantuan Hukum secara nonlitigasi oleh Paralegal sebagaimana dimaksud dalam Pasal 10 dilakukan melalui kegiatan:
a. Penyuluhan hukum;
b. Konsultasi hukum ${ }^{7}$;
c. Investigasi perkara, baik secara elektronik maupun nonelektronik;
d. Penelitian hukum;
e. Mediasi $^{8}$;

ARNOL SINAGA, S.H., ASEP DEDI, S.H., INDRA RUSMI, S.H., FISTA SAMBUARI, S.H., ALVIN MARINGAN, S.H., TEUKU MUTTAQIN, S.H., dan ENDIN, S.H., melawan MENTERI HUKUM DAN HAK ASASI MANUSIA REPUBLIK INDONESIA.

\footnotetext{
${ }^{7}$ Konsultasi dapat melibatkan individu dalam suatu komunitas, kelompok sosial dan stakeholder, yang merefleksikan komposisi dari populasi dan organisasi dari suatu area. Lihat Mukti Arto, Praktek Perkara Perdata pada Pengadilan Agama. Pustaka Pelajar, Yogyakarta, 1998, hal. 37.

${ }^{8}$ Secara umum, mediasi dapat dibagi kedalam dua jenis yakni Mediasi dalam Sistem Peradilan dan Mediasi di Luar Pengadilan. Mediasi yang berada di dalam pengadilan diatur oleh Peraturan Mahkamah Agung (PERMA) No. 1 Tahun 2008 yang mewajibkan ditempuhnya proses mediasi sebelum pemeriksaan pokok perkara perdata dengan mediator terdiri dari hakim-hakim Pengadilan Negeri tersebut sedangkan mediasi di luar pengadilan ditangani oleh mediator swasta, perorangan, maupun sebuah lembaga independen alternatif penyelesaian sengketa. Lihat Yahya
} 
f. Negosiasi;

g. Pemberdayaan masyarakat ${ }^{9}$;

h. Pendampingan di luar pengadilan; dan/atau

i. Perancangan dokumen hukum.

Jika dibandingkan dengan ketentuan dalam Pasal 1 angka 2 Undang-Undang No. 18 Tahun 2003 Tentang Advokat, maka ketentuan dalam Pasal 13 Permenkumhan di atas masih memberikan ruang bagi Paralegal untuk melakukan sesuatu yang bisa dibilang sebagai kewenangan seorang Advokat. Dimana dalam Pasal 1 angka 2 UndangUndang No. 18 Tahun 2003, menentukan bahwa jasa hukum adalah jasa yang diberikan Advokat berupa memberikan konsultasi hukum, bantuan hukum, menjalankan kuasa, mewakili, mendampingi, membela, dan melakukan tindakan hukum lain untuk kepentingan hukum klien.

Akan tetapi hal ini dapat dimaklumi mengingat profesi Paralegal itu adalah bisa dibilang sebagai penunjang profesi Advokat. Dimana dalam menjalankan tugasnya, Paralegal berada di bawah pengawasan Pemberi Bantuan Hukum. ${ }^{10}$ Selain memberikan Bantuan Hukum sebagaimana dimaksud dalam Pasal 10,

Harahap, Hukum Acara Perdata Gugatan, Persidangan, Penyitaan, Pembuktian, dan Putusan Pengadilan, Sinar Grafika, Jakarta, 2005, hal. 140.

9 Pengejewantahan (delivery) ide pemberdayaan hukum masyarakat menjadi aktivitas-aktivitias derivatif hendaknya dilakukan dengan cara yang tidak hanya inovatif, tetapi juga adaptif dan benarbenar dapat diterapkan (aplikatif) untuk menciptakan kehidupan yang lebih baik. Lihat LBH Masyarakat, Wajah Pemberdayaan Hukum Masyarakat, Pelitaraya Selaras, Jakarta, 2010, hal. 94.

${ }^{10}$ Lihat dalam Pasal 1 angka 2 Peraturan Menteri Hukum dan Hak Asasi Manusia Nomor 1 Tahun 2018 Tentang Paralegal Dalam Pemberian Bantuan Hukum. Pemberi Bantuan Hukum adalah lembaga bantuan hukum atau organisasi kemasyarakatan yang memberi layanan Bantuan Hukum berdasarkan Undang-Undang Nomor 16 Tahun 2011 tentang Bantuan Hukum.
Paralegal dapat memberikan pelayanan hukum berupa:

a. Advokasi kebijakan perangkat daerah tingkat desa/kelurahan sampai dengan tingkat kabupaten/kota;

b. Pendampingan program atau kegiatan yang dikelola oleh kementerian, lembaga pemerintah nonkementerian, pemerintah daerah provinsi, pemerintah daerah kabupaten/kota, atau pemerintah desa; dan/atau

c. Bekerja sama dengan penyuluh hukum untuk membentuk dan/atau membina kelompok keluarga sadar hukum. ${ }^{11}$

Sementara itu, Paralegal menurut peraturan peundang-undangan yang berlaku di Indonesia sampai saat ini dapat diuraikan sebagai berikut :

a. Undang-Undang Republik Indonesia Nomor 2 Tahun 2004 tentang Penyelesaian Perselisihan Hubungan Industrial, Pasal 87 ditentukan bahwa paralegal dapat dipadankan sebagai serikat pekerja/ serikat buruh dan organisasi pengusaha yang dapat bertindak sebagai kuasa hukum untuk beracara di pengadilan Hubungan Industrial untuk mewakili anggotanya.

b. Undang-Undang Republik Indonesia Nomor 23 Tahun 2004 tentang Penghapusan Kekerasan Dalam Rumah Tangga, Pasal 10 huruf (d) dan Pasal 23 huruf (b) ditentukan bahwa paralegal dapat dipadankan sebagai relawan sosial yang memberikan pendampingan dan bantuan hukum kepada korban untuk setiap tingkat proses pemeriksaan, mulai dari tingkat

\footnotetext{
${ }^{11}$ Lihat Pasal 14 ayat (1) Peraturan Menteri Hukum dan Hak Asasi Manusia Republik Indonesia Nomor 1 Tahun 2018 Tentang Paralegal Dalam Pemberian Bantuan Hukum.
} 
penyidikan, penututan, atau sampai pada tingkat pemeriksaan pengadilan termasuk meminta kepada pengadilan untuk mendapatkan penetapan perlindungan sesuai dengan ketentuan peraturan perundangudangan dengan membimbing korban untuk secara objektif dan lengkap memaparkan kekerasan dalam rumah tangga yang dialaminya.

c. Undang-Undang Republik Indonesia Nomor 32 Tahun 2009 tentang Perlindungan dan Pengelolaan Lingkungan Hidup, Pasal 91 ayat (2) ditentukan bahwa paralegal dapat dipadankan sebagai masyarakat yang berhak mengajukan gugatan perwakilan kelompok untuk kepentingan dirinya sendiri dan/atau untuk kepentingan masyarakat apabila mengalami kerugian akibat pencemaran dan/atau kerusakan lingkungan hidup.

d. Undang-Undang Republik Indonesia Nomor 16 Tahun 2011 tentang Bantuan Hukum, Pasal 9 huruf (a), paralegal dapat dipadankan dengan dosen dan mahasiswa fakultaas hukum untuk menjalankan fungsi kebantuan hukum.

e. Undang-Undang Republik Indonesia Nomor 11 Tahun 2012 tentang Sistem Peradilan Pidana Anak, Pasal 68 paralegal dapat dipadankan sebagai Pekerja Sosial dan Profesional dan Tenaga Kesejahteraan Sosial yang bertugas membimbing membantu, melindungi, dan mendampingi Anak dengan melakukan konsultasi sosial dan mengembalikan kepercayaan diri anak yang berhadapan dengan sistem peradilan pidana baik sebagai korban, saksi, maupun tersangka/terdakwa. f. Peraturan Menteri Hukum dan Hak Asasi Manusia Nomor 1 Tahun 2018 Tentang Paralegal Dalam Pemberian Bantuan Hukum. Peraturan ini secara khusus mengatur tentang Paralegal, meskipun pada akhirnya ketentuan dalam Pasal 11 dan Pasal 12 Peraturan tersebut telah dibatalkan oleh Mahkamah Agung. Namun ketentuan dalam pasal-pasal lainnya masih berlaku dan menjadi landasan hukum bagi Paralegal.

Paralegal jelas bukan Advokat tau pengacara praktek karena memang mereka tidak akan menjalankan peran Advokata atau pengacara praktek dalam pembelaan di depan pengadilan. Pekerjaan utama Paralegal adalah memberi nasehat hukum, mendokumentasikan kasus-kasus hukum yang dihadapi masyarakat miskin yang dilayaninya, membantu menumbuhkan kemampuan sosial masyarakat (pengorganisasian masyarakat), mendampingi masyarakat miskin dalam suatu proses perundingan guna mencari suatu penyelesaian dalam Perselisihan hukum dan sebagainya. ${ }^{12}$

Menurut Abdul Hakim, G. Nusantara paralegal adalah Para sarjana muda hukum, pemuka masyarakat pekerjapekerja lembaga-lembaga swadaya masyarakat yang telah mengikuti kursus pendidikan hukum kilat yang biasanya diselenggarakan oleh kantor-kantor Lembaga Bantuan Hukum berperaktek sebagai penasehat hukum masyarakat miskin atau masyarakat yang kurang mampu atau tidak diuntungkan dalam pembangunan. ${ }^{13}$ Konsep bantuan hukum itu sendiri dipergunakan sebagai terjemahan dari dua istilah asing yang

\footnotetext{
12 Lihat Pengantar Abdul Hakim G Nusantara dalam Buku Penuntun Untuk Pelatihan Paralegal, Yayasan Lembaga Bantuan Hukum Indonesia (YLBHI), Jakarta, 1989, hal. xii.

13 Mulyana W. Kusumah, Paralegal dan Akses Masyarakat terhadap Kedilan, YLBHI, Jakarta, 1991, hal. 29.
} 
berbeda, yaitu legal aid dan legal assistence. ${ }^{14}$ Secara umum, istilah paralegal menggambarkan seseorang yang telah mendapatkan pelatihan khusus dalam bidang pengetahuan dan keterampilan hukum untuk memberikan informasi dan bantuan guna menyelesaikan masalah-masalah hukum. Paralegal secara umum diawasi oleh para advokat terlatih.

Paralegal merupakan sebutan yang muncul sebagai reaksi atas ketidakberdayaan hukum dan dunia profesi hukum untuk memahami, menangkap serta memenuhi berbagai kebutuhan sosial (hak-hak masyarakat). ${ }^{15}$ Paralegal berbasis komunitas secara umum akan memainkan peranan antara lain sebagai berikut:

a. Mendidik dan melakukan penyadaran hukum;

b. Melakukan analisa sosial;

c. Melakukan advokasi (termasuk pengawasan peradilan);

d. Pendampingan, mediator;

e. Memberikan bantuan hukum;

f. Membangun jaringan kerja;

g. Memberikan dorongan;

h. Mendokumentasikan kasus-kasus;

i. Membantu menyusun konsep;

j. Membantu 'menerjemahkan' atau menjelaskan masalah hukum (pada komunitas);

k. Mendorong terbentuknya Organisasi Masyarakat; dan

1. Membantu dan bekerjasama Pengacara/Advokat. ${ }^{16}$

${ }^{14}$ Bambang Sunggono dan Aries Harianto, Bantuan Hukum dan Hak Asasi Manusia, Mandar Maju, Bandung, 2009, hal. 9.

${ }^{15}$ LBH Makasar, Buku Panduan Sekolah Paralegal Maksar, Makasar, 2005, hal. 8.

${ }^{16}$ Ibid., hal. 10.
Itulah peranan Paralegal dalam menjalankan tugasnya demi membantu memberikan akses yang seluas-seluasnya bagi masyarakat miskin untuk mencari dan menemukan keadilan dalam kehidupan bermasyarakat, berbangsa, dan bernegara.

Bahwa setelah memperhatikan secara detail uraian tentang peranan dan kedudukan Paralegal baik menurut ketentuan dalam peraturan perundangundangan yang berlaku, maupun pendapat-pendapat para ahli hukum, maka pada pripsipnya Paralegal itu ialah mereka yang telah diberikan pelatihan oleh Pemberi Bantuan Hukum yakni Lembaga Bantuan Hukum (LBH) atau Organisasi kemasyarakatan yang memberi layanan bantuan hukum untuk masyarakat miskin. Oleh karena itu, inilah perananan dan kedudukan Paralegal dalam pemberian bantuan hukum bagi masyarakat miskin, lebih khususnya adalah masyarakat yang kurang mampu secara ekonomi atau termarjinalkan.

\section{PENUTUP}

Peranan dan Kedudukan Paralegal Dalam Pemberian Bantuan Hukum Bagi Masyarakat Miskin di Kabupaten Bojonegoro adalah sebagai penunjang pelaksanaan tugas dan fungsi Advokat pada Lembaga Bantuan Hukum (LBH) dalam proses pemberian bantuan bagi masyarakat yang kurang mampu, berupa mendidik dan melakukan penyadaran hukum, melakukan analisa sosial, melakukan advokasi (termasuk pengawasan peradilan), pendampingan, mediator, memberikan bantuan hukum, membangun jaringan kerja, memberikan dorongan, mendokumentasikan kasuskasus, membantu menyusun konsep, membantu 'menerjemahkan' atau menjelaskan masalah hukum (pada komunitas), mendorong terbentuknya Organisasi Masyarakat, dan membantu serta bekerjasama dengan Pengacara/Advokat. Perlu dilakukan 
sosialisasi yang memadai kepada masyarakat khususnya di wilayahwilayah yang agak terpencil atau kurang bisa diakses terkait dengan fungsi dan peran Paralegal dalam proses pemberian bantuan hukum bagi masyarakat miskin. Kemudian pendidikan pelatihan Paralegal perlu ditingkatkan lagi dalam rangka meningkatkan kualitas sumber daya manusia Paralegal dalam memberikan bantuan hukum secara cuma-cuma bagi masyarakat yang membutuhkannya.

\section{DAFTAR BACAAN}

\section{Buku:}

A Mukti Arto. (1998). Praktek Perkara Perdata Pada Pengadilan Agama, Yogyakarta: Pustaka Pelajar.

Bambang Sunggono dan Aries Harianto. (2009). Bantuan Hukum dan Hak Asasi Manusia, Bandung: Mandar Maju.

Lembaga Bantuan Hukum. (2005). Buku Panduan Sekolah Paralegal Maksar, Makasar: LBH Makasar.

LBH Masyarakat. (2010). Wajah Pemberdayaan Hukum Masyarakat, Jakarta: Pelitaraya Selaras.

Mulyana W. Kusumah. (1991). Paralegal dan Akses Masyarakat terhadap Kedilan, Jakarta: YLBHI.

Peter Mahmud Marzuki. (2009). Penelitian Hukum, Cet. 5, Edisi Pertama, Jakarta: PT Interpratama Offset. (2010). Penelitian Hukum, Jakarta:

Kencana Prenada Media Group.
Yahya Harahap. (2005). Hukum Acara Perdata Gugatan, Persidangan, Penyitaan, Pembuktian, dan Putusan Pengadilan, Jakarta: Sinar Grafika.

Yayasan Lembaga Bantuan Hukum Indonesia. (1989). Buku Penuntun Untuk Pelatihan Paralegal, Jakarta: YLBHI. (2014). Panduan Bantuan Hukum Indonesia, Jakarta: Yayasan Obor Indonesia.

Peraturan perundang-undangan:

Undang-Undang Dasar Negara Republik Indonesia Tahun 1945.

Undang-Undang Republik Indonesia Nomor 18 Tahun 2003 Tentang Advokat.

Undang-Undang Republik Indonesia Nomor 2 Tahun 2004 Tentang Penyelesaian Perselisihan Hubungan Industrial.

Undang-Undang Republik Indonesia Nomor 23 Tahun 2004 Tentang Penghapusan Kekerasan Dalam Rumah Tangga.

Undang-Undang Republik Indonesia Nomor 32 Tahun 2009 Tentang Perlindungan dan Pengelolaan Lingkungan Hidup.

Undang-Undang Republik Indonesia Nomor 16 Tahun 2011 Tentang Bantuan Hukum.

Undang-Undang Republik Indonesia Nomor 11 Tahun 2012 Tentang Sistem Peradilan Pidana Anak.

Peraturan Menteri Hukum dan Hak Asasi Manusia Nomor 1 Tahun 2018 Tentang Paralegal dalam Pemberian Bantuan Hukum. 